\title{
AN OVERVIEW OF WAQF ASSETS IN YEMEN: IMPORTANCE AND CHALLENGES
}

\author{
Abdo Yousef Qaid Saad ${ }^{1}$, Mustafa Omar Mohammed ${ }^{2}$, Ibrahim Al-Jubari ${ }^{3}$ \\ ${ }^{1}$ Institute of Islamic Banking and Finance, International Islamic University Malaysia, ${ }^{2}$ Kulliyyah Of Economics and \\ Management Sciences, International Islamic University Malaysia, ${ }^{3}$ Faculty of Business Management and Professional \\ Studies, Management \& Science University, Malaysia. \\ Email: 1abdoiibf@hotmail.com, 2mustafa@iium.edu.my, 3aljubari@msu.edu.my
}

Article History: Received on $21^{\text {st }}$ August 2019, Revised on $29^{\text {th }}$ September 2019, Published on $05^{\text {th }}$ November 2019

\section{Abstract}

Purpose of Study: Waqf has played a significant role throughout Islamic history. This has been possible through proper management, investment and financing of various Waqf assets to enhance the socioeconomic development of Muslim societies. In particular, it has contributed significantly to the encouragement of religious practices, improvement of education, health and helping the poor and the needy, creating employment and supporting other socio-economic activities.

Methodology: The current study attempted to uncover these challenges facing by Waqf institution in Yemen. Particularly, issues such as management, investment and finance will be emphasized.

Results: However, nowadays most of Waqf assets have become idle and no longer serves the needs of the Ummah due to problems, such as poor governance structure and human resource. Few studies have tried to address challenges facing Waqf but unfortunately these studies have been conducted in countries where the governance structure is robust and the quality of human resource is very good. Such models may not be suitable in contexts such as Yemen where Waqf assets are mostly in the form of physical assets such as lands and buildings and the quality of human resource and governance structure are poor.

Keywords: Assets, WAQF, Yemen, Ummah, Waqf management.

\section{INTRODUCTION}

Waqf - an endowment of physical or financial asset with earning potential - has played a significant role throughout Islamic history (Çizakça, 2000). The central role of Waqf in Muslim community was described by historian Marshall Hodgson in (Singer, 2008; Jayathilaka and Purasinghe, 2017) as 'the vehicle for financing Islam as a society' supporting cultural, religious, social and economic activities, meanwhile serving political functions. Numerous literatures on Waqf institutions have also uncovered the key role of Waqf that contributed to the communities and states (Layish, 1983; Powers, 1989; Cizakca, 1998; Çizakça, 2000; Nagata, 2002; Mahamood, 2006; Abu-Zahrah, 2007; Latiff, 2008; Singer, 2008; Mohsin, 2009; Abdallah, 2010; Wafa and Wafa, 2010).

Additionally, Waqf institution has been significantly contributed to the Muslim communities through improved religious practices, enhancing education and knowledge, in addition, to transmit culture among the Muslim communities. For example, the first mosque was erected in Madinah by Prophet Mohammed (PBUH), the basic role of the mosque had to improve the practices of religious and considered as centre of the education, administration, and culture (Latiff et al., 2006; Abu-Zahrah, 2007; Latiff, 2008; Joshua, 2016). From then, donating mosques and related institutions has been common in Muslim societies. Religious schools for memorizing the Qur'an and the primary education, as well as libraries, were created for enjoyed the benefits of Waqf. Some of these religious schools later developed and became higher institutions. The university of al-Qarawiyin was the oldest university in Morocco and it greatest example of the interference of Waqf in developing higher education (Raissouni, 2001). In like Waqf manner, Al-Azhar University in Egypt has received resources to finance its operation (Çizakça, 2000; Kabir and Aftab, 2017). This shows that Waqf was managed properly, where it has played a significant role to finance such these educational institutions. This turn, led to the Waqf development through generating more income that had encouraged Waqf to expand its activities.

In Yemen, In Yemen, Waqf institution has significantly contributed in socioeconomic and cultural development, it has contributed to achieve the type of social solidarity in Yemeni community through aiding needy and poor people, providing free shelter, free education, building hotels and houses in addition to help poor for performing pilgrimage at Mecca (Al arashi, 2014). On the educational level, Awqaf were contributed to education through building many schools with fully financial support by waqf institutions, where these schools provide free education to people from elementary school until University. Waqf also has contributed direct or indirect in increasing Yemen's GDP by farming the waqf lands such as Al dhabab valley and Zabeed (Al-Sorori, 1997; Kanwal et al., 2017). Therefore, there are many farming lands which are widely spread in all over of Yemen, most of these farming lands produce high amount of fruits, grains and vegetables, which are estimated at 15-20\% percent of total farming lands in Yemen (mujahid, 1978). Presently, the Ministry of Waqf in Yemen has established many commercial centers in addition to markets and rents them to people in order to gain profits and promote investment. For instance, there are more than 4000 Shops in the city of Sana'a alone (Kareem et al., 2017). Thus, the kinds and purposes of waqf in Yemen continue to vary, according to the Ministry of waqf in Yemen, there are more than 150 kinds of waqf; the most important are Awqaf for mosques which are numbered at an estimate to 75 thousand mosques, educational institutions, medical facilities, animal care, and for other social purposes (Abdo, 1997). 
Despite Waqf potential and its contribution towards the socio economic development in Yemen, the institution continues to face numerous challenges which unfortunately have been neglected in the literature. Therefore, the current study attempts to uncover these challenges facing by Waqf institution in Yemen. Particularly, issues such as management, investment and finance will be emphasized.

\section{The context of Yemen}

Yemen is located in the southern half of the Arabian Peninsula, bordering the Red Sea, Gulf of Aden, and the Arabian Sea. To the north, it is bordered by Saudi Arabia and in the east by Oman in addition to maritime borders with Eritrea, Djibouti, and Somalia. Yemen has a total land area of 527,970 square kilometres with a population of close to 27 million (Fund, 2015) and Islam is the official religion of the country. Around $98 \%$ of Yemenis are Muslims and the remaining $2 \%$ are Non-Muslim (Kyrychenko, 2018). Yemen is classified as one of the least developed countries in the region with around $42 \%$ of the population living under the poverty line. Moreover, Yemen is ranked 149 out of 171 in terms of human resource development and has a growing unemployment rate which reached approximately 35\% in 2008 (Al-Swidi and Mahmood, 2011). Nevertheless, Yemen is well-known as one of the most active intercontinental shipping hubs in the world based on its strategic commercial location at the entrance of the Bab el Mandeb, which links the Red Sea to the Indian Ocean through the Gulf of Aden (Bafadle, 2010).

Yemen has the potential to develop into a propitious country since it is very rich in great economic resources. There is much wealth that has not been utilized economically until now, particularly in the fields of gas, oil, fishing, and other resources. For example, agriculture and fishing represent between 15-20\% of the gross domestic product GDP. The arable land consists of only $3 \%$ of the whole area of Yemen. The actual cultivated area is $77 \%$ of the total cultivable area. The contribution of the oil sector to the gross domestic production reaches the rate of about $20-30 \%$ and constitutes around $75 \%$ of state revenues (Al-Yemeni, 2003).

\section{An Overview of Waqf in Yemen}

Historically, as an extension of the Muslim Caliphate, Waqf contributed significantly in Yemen from the advent of Islam until ten decades ago. For example, the big mosque in Sanaa was the first Waqf in Yemen that was built by Farwa, the companion of the Prophet (PBUH). Another companion, Muadh bin Jabal, built the Junaid Mosque when the Prophet (PBUH) sent him to Yemen to teach people Islam. The subsequent period that marked the Rasulillah state witnessed the peak of Waqf expansion.

In fact, it is considered the golden period of Waqf development in Yemen. For example, Waqf was used to finance education in the form school buildings and other educational facilities. These schools provided free education to people from elementary until the university level. There were about 115 schools built during Al-Rasulillah state in Yemen, fully financed by the Waqf institutions. These schools contributed to Islamic knowledge as well as other sciences. It provided free education for international students (Al-Akwa, 1986). Waqf activities in Yemen continued to spread during the rule of the Ottoman caliphate, where several mosques and schools had been established. For example, Ash'aris mosque in Zabeed and Mustafa Basha' school as well as Al- Alexandria school in Sana'a, among others (Al-Akwa, 1986).

Today in Yemen Waqf is still a significant institution with huge potentials in terms of the existing asset size and the country's resources which can be used as new sources for Waqf. According to Abdul Rahman Al-Qulam, Deputy of awqaf ministry and Saleh Ali Khamis, General Manager of awqaf in the city of Mahesh (2018) they asserted that around 240,000 Square kilometres. This constitutes 48 percent, almost a half of the entire land area of Yemen. Additionally, a huge size of moveable and immoveable assets owned by Waqf institutions in Yemen (Awqaf, 1991). In fact, people hardly can find land which is not owned under the Waqf assets. Many Waqf farming lands that are widely spread in Yemen today are the results of past efforts in financing the sector. Most of these farming lands produce large amount of fruits, grains and vegetables (mujahid, 1978).

Recently, there have been discernible efforts from the Ministry of Awqaf in Yemen towards developing Waqf assets. For example, the Ministry established many commercial centres and rented them to people to gain profits and promote investment. There are more than 4000 shops in the city of Sana'a alone (Margaret-Anne and Donna, 2018).

\section{The role of Waqf for social and economic development}

It is noted that, waqf has widely spread in all over of Yemen; it has clearly contributed in the social and economic development as well as cultural. These contributions are discussed as follow.

\section{Contribution of Waqf in enhancing education process}

Waqf institution has contributed to education through building many schools with fully financial support from waqf, where these schools provide free education to people from elementary school until University. Whereas, there was not any support from Government budget to education. Therefore, the waqf has provided financial support for students in addition to education activities. In the time of Al-Rasulillah state, around 115 schools were built and paid by the waqf institution. All these schools were not only contribute to the Islamic knowledge but also it contributed to other sciences. Meanwhile, students came from all over the world to Yemen in order to obtain the knowledge. 


\section{Contribution of Waqf in Poverty Alleviation}

Waqf institution has contributed to achieve the type of social solidarity in Yemeni community through aiding needy and poor people, providing free shelter, free education, building hotels and houses in addition to help poor for performing pilgrimage at Mecca (Al arashi, 2014).

\section{Contribution of Waqf in operation and production}

waqf institution has contributed direct or indirect in increasing Yemen's GDP by farming the waqf lands such as Al dhabab valley and Zabeed (Al-Sorori, 1997). In addition, there are many farming lands which are widely spread in all over of Yemen, most of these farming lands produce high amount of fruits, grains and vegetables, and it contributes around 15$20 \%$ percent of total farming lands in Yemen (mujahid, 1978). Besides that, waqf contributes in commercial field through created commercial centers, public markets and so on. According to Margaret-Anne and Donna (2018) he stated that there are more than 4000 Shops in the city of Sana'a. waqf also contributes in production process by employing workers in waqf institutions. Presently, the Ministry of Awqaf in Yemen has established many commercial centers in addition to markets and rents them to people in order to gain profits and promote investment (Awqaf, 1991).

\section{Contribution of Waqf in distribution and redistribution}

The waqf has significantly contributed in a better income distribution to those who are needy, workers and poor, where it contributes to ensure the income to needy people. However, waqf contributes in redistribution through keeping wealth trading and providing benefits of that for poor Categories by free (Margarita et al., 2018).

In the light of the aforementioned significance of Waqf system in Yemen, Waqf had played its historical role significantly in the socio-economic development. Because of the size of assets, various types that they have. As illustrates in the following sections:

\section{Types of Waqf in Yemen}

The kinds and purposes of waqf in Yemen continue to vary. According to the Ministry of Waqf in Yemen, (2014) there are more than 150 kinds of waqf; the most important are Awqaf for mosques which are numbered at an estimate to 75 thousand mosques, educational institutions, medical facilities, animal care, and for social purposes. Some of these types of waqf in Yemen are discussed next.

\section{Awaqf for the Mosques}

In Yemen, many of wqaf has created to religious aspects such as the mosque, as discussed in the early part of this chapter, The big mosque in Sanaa was the first waqf in Yemen and was built by Farwa Al-Moradi the companion of the Prophet (PBUH) followed by the al-junaid mosque which was created by Ali Bin Abi Talib, the fourth caliph in Islam. And waqf continued from that time until today. Therefore, the waqf have a lot of the farming lands, shops, estate and caravanserais. The income from an endowment would pay for the maintenance costs of the mosques (Mingchang et al., 2018).

\section{Awaqf for the educational institutions}

Educational waqf has spread widely around of Yemen; the schools were opened for all level of people alike which are numbered at an estimate to 193 schools. All these schools were created by wqaf and they are still sponsored by waqf until today and they provide free education to people from elementary school until University. Thus, there are still waqf for scientific institutes such as Al-Bihani institute in Aden (akwa, 1986).

\section{Awaqf for Poor and Needy}

Some waqf were established to help needy and poor people such as blind and patients through providing aids like clothes, shelter and food. In regard of health, many hospital buildings and centre of treatments were built and paid by the waqf. Therefore, there are awqaf for leprous and mentally ill, this kind of waqf still continued until today and managed by the Ministry of Health (Awqaf, 1991).

\section{Awqaf for Books}

Beside the created educational institutions by waqf, there's waqf for books whether religious or other books of sciences. Yemeni scholars gave attention for writing and copy books, many of these books were distributed to schools and libraries in Yemen. In addition, there are some people who has written number copies of the Quran and distributed it to different places in Yemen. The existence of two prominent libraries, namely, the big Mosque library in Sana'a and Al-Mudhafar Mosque in Taiz (Awqaf, 1991; Awqaf, 1991).

\section{Awqaf for Infrastructure and wells}

Waqf has played a role in terms of Building bridges and Dams as well as the maintenance of other related infrastructures such as public road and facilities. Meanwhile, waqf contributed in building houses and refuges for needy People (Awqaf, 1991). 
There are many types of waqf distributed at different aspects such as Social, educational, health, infrastructure and others. Following figure is shown many of these kinds.

Based on the above figure, it can be concluded that Waqf has played an important role in social and economic development to the society in Yemen. These contributions of the Waqf demonstrated that Waqf was properly managed to provide welfare services which many institutions struggle to offer. Therefore, good management, investment, and financing greatly contributed to the flourishing of Waqf. All these will be illustrated in the following discussion.

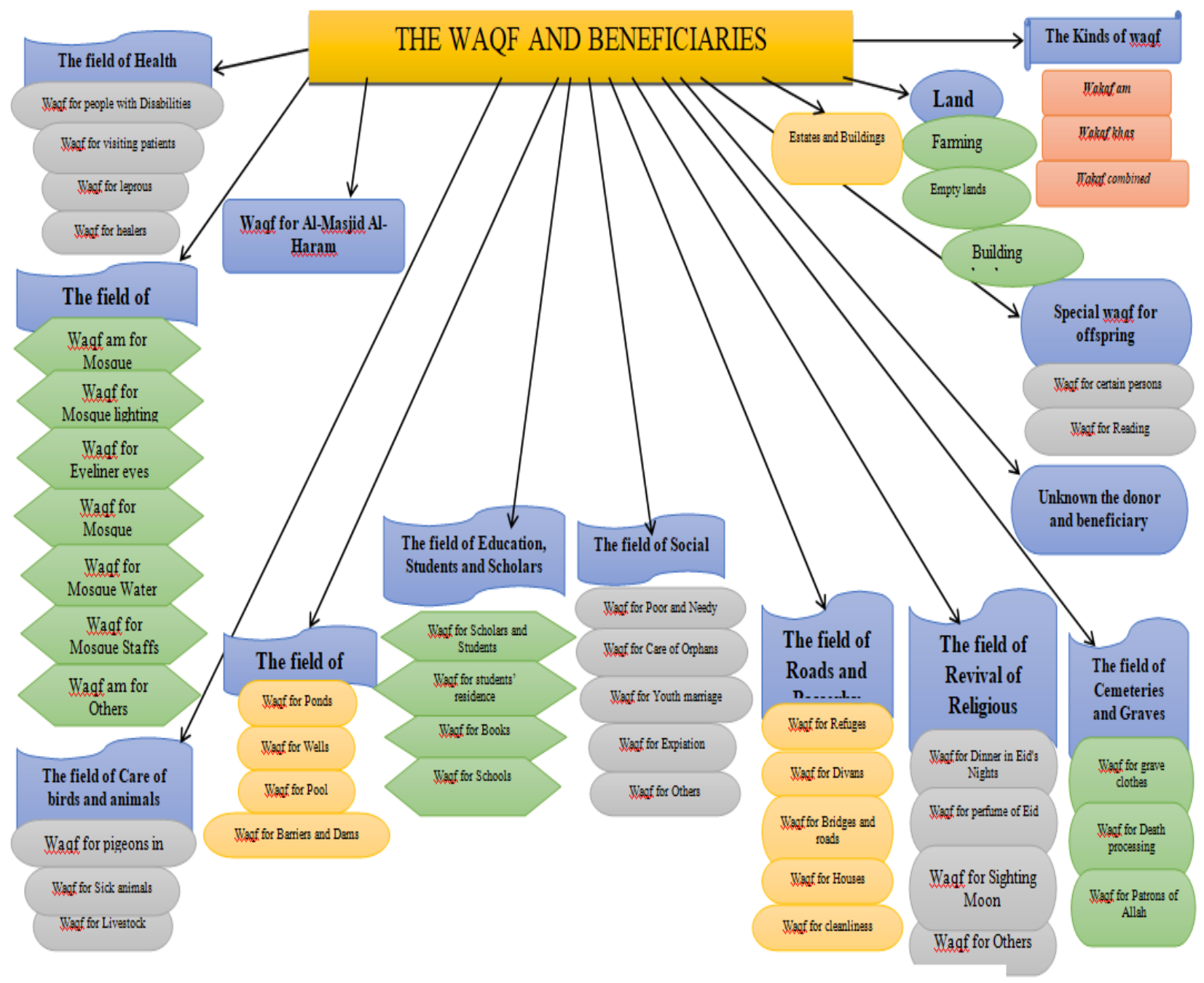

Figure 1: The Waqf and beneficiaries

Source: Translated by the Author from Arabic to English, from the Ministry of Awqaf in Yemen, 2015.

\section{Management, Investment and financing of Waqf Assets}

Due to the rich types of Waqf, it has a huge potential to be utilized in social and economic development. To ensure the implementation of Waqf activities and its potentials, there is a need to create sound governance structure and human resource as well as finance and invest Waqf asset properly. In the light of this theme, the following sections discuss the management, investment and financing of Waqf assets in Yemen (Awqaf, 1991). Mutawalli was primarily responsible for the administration and act as trustee. In order to protect and to develop Waqf assets and achieve the best benefits for the founder and the beneficiaries alike (Al-Akwa, 1986; Al-Sorori, 1997). During Al-Rasuliyah state, Waqf management was nationalized and transferred the responsibility from individual administrator to the judge's institution (Al-Janadi, 1993). A similar fate was experienced during Ottoman Empire. Waqf has taken place under the umbrella of the Islamic courts, which was divided in independent administrations. At this time, the Waqf assets and lands were well monitored and constantly recorded development. During Al-Imam rule, the practice of Waqf administration during Imam Yahya and his sons continued as it was by government in 1919. But, most of the Waqf assets were not well managed and some of Waqf lands were manipulated for non-charitable purposes (Abdo, 1997). After the revolution 26 September 1962, Waqf administration was fully under the control of the Ministry of Awqaf, which had been appointed as the trustee for its management (Awqaf, 1991).

Recently, most of Waqf is managed by the Ministry of Awqaf, however, part of it still managed by other institutions. For example, Waqf on the educational purposes is managed by the Ministry of Education and Waqf on healthcare is 
administered by the Ministry of health as well as agriculture lands are managed through the Ministry of farming. The Ministry acts as supervise and monitor all Waqf activities included registration, maintenance, and development of Waqf assets. Mutawalli is appointed by the ministry to administer Waqf for for the benefit of beneficiaries (Abdo, 1997). Besides the management of Waqf assets, the Ministry of Awqaf also has to deal with many other religious issues such as Haj, mosques, and the appointment of imams. It is almost impossible for an individual to offer a combination of these services. Thus, the appointment of an individual Mutawallis to manage each Waqf assets may not be feasible. There is a vital need to institutionalize the office of the Mutawalli. The institution is always better than a single Mutawalli as it has the advantage of team expertise and professional administration that an institutional Mutawalli could be offered. Furthermore, an institutional Mutawalli can also easily and efficiently manage many Waqf assets for the benefit of beneficiaries.

Similarly, Waqf has taken various forms of investment and financing Waqf assets. The Ministry of Awqaf has decided to create an independent administration for Waqf investment. This administration acts to find more effective methods and approaches which can be adopted to raise the income of the Waqf assets (Awqaf, 1991). In fact, Waqf has utilized to provide finance for religious purposes such as Mosques. In addition, most of Waqf investments are mainly focused on the Real Estate such as buildings, shops and residential apartments (Awqaf, 1991). These investments will be illustrated in the following table 1 .

In addition, the Ministry has established many Waqf investments between the years 1980-1987. For example, Sam Hotel, 4 buildings, and other Residential buildings were estimated to be 73 Million Yemeni Rial. As such, most of Waqf assets were used to provide finance for Mosques. Waqf institution has significantly contributed in improving mosques in order to maintain and refurbishment them. Additionally, Waqf has contributed to the financial establishments for new mosques. Over 50 thousand mosques were financed through Waqf assets. The table 2 shows many mosques funded by Waqf:

Table Error! No text of specified style in document.: Summary of Waqf Investment Projects in Yemen (WIPY)

\section{$\begin{array}{lll}\text { NO. TYPE OF PROJECT } & \text { COST } & \text { ( YEMENI RIAL) }\end{array}$}

\begin{tabular}{|c|c|c|c|c|}
\hline 1 & Commercial / Residential & $5,526,604$ & Sana'a & $\begin{array}{l}50 \text { trade fair and } 12 \\
\text { apartments }\end{array}$ \\
\hline 2 & Commercial / Residential & $8,731,800$ & Sana'a & $\begin{array}{lr}21 \text { trade fair and } 27 \\
\text { apartments }\end{array}$ \\
\hline 3 & Commercial / Residential & $3,600,000$ & Sana'a & $\begin{array}{l}7 \text { trade fair, } 24 \text { apartments } \\
\text { and } 1 \text { store }\end{array}$ \\
\hline 4 & Commercial / Residential & 734,510 & Sana'a & 2 trade fair and 2 apartments \\
\hline 5 & Residential & $4,586,695$ & Sana'a & 24 apartments \\
\hline 6 & Central Market & $63,150,000$ & Sana'a & $\begin{array}{llll}\text { Four-storey stores and } 1 \\
\text { Butchery }\end{array}$ \\
\hline 7 & $\begin{array}{l}\text { Commercial Complex / } \\
\text { Residential }\end{array}$ & $1,500,000$ & Saadah & 12 trade fair \\
\hline 8 & Commercial / Residential & $5,650,000$ & Sana'a & $\begin{array}{lr}61 & \text { Trade fair and } 5 \\
\text { Apartments } & \end{array}$ \\
\hline 9 & Central Market & $1,426,171$ & Thamar & 33 Trade fair \\
\hline 10 & Trade fairs & $1,131,000$ & Thamar & 27 fair \\
\hline 11 & Central Market & $2,344,000$ & Thamar & 13 fair \\
\hline 12 & Central Market & 146,000 & Thamar & 20 fair \\
\hline 13 & Hotel & 510,000 & Al Hudaydah & 16 Rooms and 3 fairs \\
\hline 14 & Shops & 200,000 & Al Hudaydah & 3 fairs \\
\hline 15 & Toilet and fairs & $4,600,000$ & Ibb & 16 Apartments and 20 fair \\
\hline 16 & Hotel & $3,566,000$ & Ibb & $\begin{array}{l}\text { Restaurant, } 48 \text { Rooms and } 10 \\
\text { fairs }\end{array}$ \\
\hline 17 & Commercial Certer/ Residential & $3,267,000$ & Ibb & 14 fair \\
\hline 18 & Fairs and Mosque & 800,000 & Ibb & 14 fair \\
\hline 19 & Central market & 113450 & Taiz & Apartments and Fairs \\
\hline 20 & Commercial Center & $1,138,400$ & Taiz & 20 Fair \\
\hline
\end{tabular}

Source: Translated by the Author from Arabic to English, from (Awqaf, 1991).

Table 2: Summary of Mosques Funded by Waqf in Yemen

\begin{tabular}{lll}
\hline NO. & YEAR & COST ( YEMENI RIAL) \\
\hline 1 & $1970-1971$ & $2,782,030$ \\
\hline
\end{tabular}




\begin{tabular}{lll}
\hline 2 & $1972 / 1973$ & $11,504,691$ \\
\hline 3 & $1977 / 1978$ & $31,321,150$ \\
\hline 4 & $1982 / 1983$ & $79,643,310$ \\
\hline 5 & $1988 / 1989$ & $22,933,656$ \\
\hline Total & & $\mathbf{1 4 8 , 1 8 4 , 8 3 7}$ \\
\hline
\end{tabular}

Source: Translated by the Author from Arabic to English, from (Awqaf, 1991).

In addition, the Ministry of Awqaf has budgeted 6.2 Million Rial for the purchase of mosques' furniture. Waqf was also financed for many toilet and ablution areas of mosques, over 200 units, with a total finance of 4.6 Million Rial (Awqaf, 1991). In addition, the Ministry of Awqaf has budgeted 6.2 Million Rial for the purchase of mosques' furniture. Waqf was also financed for many toilet and ablution areas of mosques, over 200 units, with a total finance of 4.6 Million Rial (Awqaf, 1991).

Despite great efforts in the development of Waqf assets in the most of the Muslim countries and Yemen specifically, it continues to face numerous challenges, mainly three: management, investment, and financing of Waqf assets. Some of these challenges are extended from the colonialism period until today, while other challenges due to the failure of the existing Waqf institutions. The following section illustrates these challenges facing by Waqf institution in Yemen.

\section{Challenges facing Waqf in Yemen}

Despite significant contribution of Yemeni waqf assets to social and economic growth, they still continue to face numerous challenges preventing their development, some prominent challenges namely: Management Challenges, Finance Challenges and Investment Challenges.

\section{MANAGEMENT CHALLENGES}

The management challenge is further classified into two major ones: the absence of good governance structure and poor quality of human resource. In practice, Waqf Institutions in Yemen have poor governance structure. They lack transparency and accountability. For example, a Waqf land manager in Sana'a reports that around 80\% of Waqf lands in the city of Sana'a have already been sold by corrupt political leaders (Awqaf, 1991). The absence of effective institution with clear vision of managing Waqf assets has led to failure in the existing system and the inability to overcome corruption. The governance problem is further aggravated by the poor quality of human resource. There is lack of professional and technical expertise for developing Waqf assets where the majority of workers in Waqf institutions are not qualified. Therefore, there is a dire need for qualified people with sufficient skills to develop strategies and enhance the administrative and organisational effectiveness (Abdo, 1997).

\section{Finance Challenges}

Financial challenges are perhaps the most pressing, where there is no sufficient resource to finance Waqf assets in Yemen. This is because the revenue generated from the Waqf land fully used to cover a wide range of expenses including the maintenance and administration of Waqf assets, which often exceed the Waqf returns (Awqaf, 1991). Besides, most of Waqf assets in Yemen are mainly into the form of immovable assets including lands and buildings, among others. Which is considered as less productive compared with moveable Waqf such as cash (Abdo, 1997). Other factors which contribute to financial challenges are Waqf institution's failure to lease out the land at a competitive rate and the failure to systematically collect rent arrears from the tenants (Al-Farran, 2013).

\section{Investment Challenges}

As such, similar fate on investment challenges in Yemen, Waqf assets are not given adequate attention and most Waqf lands are still undeveloped and unproductive (Al-Farran, 2013). All of Waqf assets in Yemen at the moment are physical assets, where much of these physical assets are in the form of lands or buildings. Meanwhile, more that 90 percent of these assets are endowed for religious purposes. Only 10 percent of these assets are used for non-religious purposes. With the present governance structure in Yemen, not much can be done to develop these assets. Therefore, there has to be an external source of financing for these Waqf assets.

\section{CONCLUSION}

Waqf has played a significant role throughout Islamic history. This has been possible through proper management, investment and financing of various Waqf assets to enhance the socioeconomic development of Muslim societies. Waqf served the Ummah in almost all aspects, such as religion, education, health and socio-economics. Although, historically, Waqf has been proven to be an effective tool in eliminating poverty, while promoting equitable wealth distribution. However, literature has shown that there is a decline in the role of the Waqf in the realization of social justice and economic development in recent time due to several challenges namely: management, investment and finance. This has led to abandonment and underdevelopment of Waqf assets in Yemen. Therefore, there is an urgent need to find qualified institution to address these challenges; institution that has trust, safety, sufficient skills and ability to accomplish this task. 


\section{REFERENCES}

1. Abdallah, T., 2010. The state and awqāf (charitable endowments) in the twenty-first century: From tutelage to partnership. Contemporary Arab Affairs, 3(4): 503-514.

2. Abdo, A.A.S., 1997. The effect of waqf in economic and social development applied study in yemen. In: postgraduate in Shariah studies. Umm Al Qura University, Saudi Arabia.

3. Abdo, A.A.S., 1997. The effect of waqf in economic and social development applied study in yemen. In: Islamic economics. Umm Al Qura University, Suadi Arabia.

4. Abu-Zahrah, M., 2007. Waqf according to religion and laws (wakaf menurut agama dan undang-undang). Puchong: Jasmin Enterprise.

5. akwa, I.A.A., 1986. Islamic schools in yemen. Beirut: Al- risalah institute.

6. Al-Akwa, I.A., 1986. Islamic schools in yemen. Beirut: Al- risalah institute.

7. Al-Farran, A.m., 2013. Current position for waqf system in yemen. In: Journal of Religion and Life. Sana'a Yemen.

8. Al-Janadi, M., 1993. Behavior in layers scholars and kings. 1 Edn., Sana'a - Yemen: Al-Ershad library.

9. Al-Sorori, M., 1997. Political life and aspects of civilization in Yemen in the era of the independent statelets: 1037-1228.

10. Al-Sorori, M., 1997. Political life and aspects of civilization in yemen in the era of the independent statelets from 1037-1228.

11. Al-Swidi, A.K. and R. Mahmood, 2011. Yemeni banking system: Critical issues and future recommended strategies. European Journal of Social Sciences, 20(4): 637-655.

12. Al-Yemeni, A.A.H., 2003. The dynamics of democratisation-political parties in yemen. Bonn (Friedrich Ebert Stiftung).

13. Al arashi, A.M., 2014. The historical experience of the management of waqf system in yemen in the era of apostolic state ( 1228 - 1454) the endowment ghassani.

14. Awqaf, M.o., 1991. Al-awqāf wa-al-irshād fỉ mawkib al-thawrah, 1962-1987. Sana'a: Al-Thawra journal.

15. Awqaf, M.o., 1991. Al-awqāf wa-al-irshād fī mawkib al-thawrah, 1962-1987 m., Yemen: al-Jumhūrīyah al'Arabīyah al-Yamanīyah, Wizārat al-Awqāf wa-al-Irshād,.

16. Bafadle, O., 2010. A study on agriculture vulnerability and adaptation to climate change

17. in the republic of yemen. E. P. Authority (Ed.). Yemen.

18. Cizakca, M., 1998. Awqaf in history and its implications for modern Islamic economies. Islamic Economic Studies, 6(1): 43-70.

19. Çizakça, M., 2000. A history of philanthropic foundations: The islamic world from the seventh century to the present. Boğaziçi University Press İstanbul.

20. Fund, I.M., 2015. Principles and recommendations for population and housing censuses. In: World Economic Outlook Database. IndexMundi.

21. Jayathilaka, A. and P.L.T. Purasinghe, 2017. Bridging the great divide between state and society (A Study on Two Initiatives of Enhancing the State? Society Synergy in Sri Lanka). Asian Development Policy Review, 5(2): 8189.

22. Joshua, O.O., 2016. Hunger and malnutrition: Review of copenhagen consensus challenge paper 2004. American Journal of Social Sciences and Humanities, 1(2): 85-99.

23. Kabir, K.H. and S. Aftab, 2017. Exploring management strategies for freshwater Wetland: Policy options for Southwest coastal region in Bangladesh. Asian Development Policy Review, 5(2): 70-80.

24. Kanwal, R., F.R. Khan and S.M. Baloch, 2017. Comparative study of linguistic features in gender communication in Pakistani television talk show. International Journal of English Language and Literature Studies, 6(2): 54-62.

25. Kareem, S.D., A.K. Olusegun and L.S. Arogundade, 2017. The link between agricultural budgetary allocation and economic growth in Nigeria. International Journal of Business, Economics and Management, 4(2): 38-43.

26. Kyrychenko, V., 2018. Indonesias higher education: Context, policy, and perspective. Asian Journal of Contemporary Education, 2(2): 159-172.

27. Latiff, A., C. Ismail and N. Daud, 2006. Waqf assets management and its potential toward the enhancement of education for muslim community in malaysia (pengurusan harta wakaf dan potensinya ke arah kemajuan pendidikan umat islam di malaysia). In: National Wakaf Seminar.

28. Latiff, A.Z., 2008. Wakaf pengurusan dan sumbangannya terhadap pendidikan islam di malaysia. Shah Alam: Pusat Penerbitan UPENA UiTM.

29. Layish, A., 1983. The mālikī family waqf according to wills and waqfiyyāt. Bulletin of the School of Oriental and African Studies, 46(01): 1-32.

30. Mahamood, S.M., 2006. Waqf in malaysia: Legal and administrative perspectives. University of Malaya Press.

31. Mahesh, P.C., 2018. Empowering youth through youth engagement in social action in India. International Journal of Innovation, Creativity and Change, 4(1): 16-28.

32. Margaret-Anne, C. and G. Donna, 2018. Potential enablers of mental health and wellness for those teaching in tertiary education. International Journal of Innovation, Creativity and Change, 4(3): 3-20. 
33. Margarita, F., L. Maureen and Y. Janelle, 2018. Educating social workers for leadership in a highly differentiated society. International Journal of Innovation, Creativity and Change, 3(4): 61-72.

34. Mingchang, W., S. Ibnu and M. Tuatul, 2018. The role of cognitive and affective behavior in predicting the creative thinking of university students. International Journal of Innovation, Creativity and Change, 4(2): 90-103.

35. Mohsin, M.I.A., 2009. Cash waqf: A new financial product.

36. mujahid, A.M.A., 1978. Ta‘̄âwun al-zirā‘'̄ madkhal lil-tanmiyah fī al-jumhūrīyah al-‘arabīyah al-yamanīyah. Cairo: Ālam al-Kutub.

37. Nagata, J., 2002. The changing perceptions of waqf, as social, cultural and symbolic capital in penang. In: International Conference-The Penang Story, Penang.

38. Powers, D.S., 1989. Orientalism, colonialism, and legal history: The attack on muslim family endowments in algeria and india. Comparative Studies in Society and History, 31(03): 535-571.

39. Raissouni, A., 2001. Islamic" waqf endowment": Scope and implications. ISESCO.

40. Singer, A., 2008. Charity in islamic societies. Cambridge University Press.

41. Wafa, S. and B. Wafa, 2010. Development of waqfs for education in malaysia. In: Seventh International Conference-The tawhidi epistemology: Zakat and waqf economy. pp: 137-153. 